\title{
Displacement of diverse ichthyoplankton assemblages by a coastal upwelling event on the Sydney shelf
}

\author{
Kimberley A. Smith*, Iain M. Suthers \\ School of Biological Science, University of New South Wales, Sydney, New South Wales 2052, Australia
}

\begin{abstract}
The influences of upwelling-favourable winds and thermocline displacement on the distribution of temperate/tropical ichthyoplankton assemblages were determined from vertically stratified plankton hauls across the Sydney shelf, southeastern Australia. Five stations were sampled along a shore-normal transect off Sydney. Australia, on 3 or 4 consecutive nights during January and April 1994. High taxonomic diversity (111 ichthyoplankton families) was attributed to the convergence of temperate and tropical waters in this region. Total larval abundance was higher in January than in April, reflecting the spawning times of many coastal taxa. In both months, highest larval density and taxonomic diversity were assaciated with the interface between the mixed layer and the thermocline. In April, a period of upwelling-favourable winds resulted in the offshore displacement of the nearshore mixed layer, as well as numerous shelf-spawned larvae (e.g. Centroberyx affinis, Chromis hypsilepsis, Arripis trutta) from the nearshore region, and coincided with the injection of deeply distributed mesopelagic larvae into the nearshore zone (e.g. Scopelosaurus sp., Melamphaes sp.). Shelf-spawned larvae were displaced to the outer shelf, where they were still associated with the mixed layer/thermocline interface. Dynamic ichthyoplankton distributions are interpretable, at least at a scale of weeks, by considering larvae as tracers of the local hydrography.
\end{abstract}

KEY WORDS: Ichthyoplankton assemblages · Hydrography · Upwelling · Thermocline

\section{INTRODUCTION}

Planktonic distributions reflect local hydrographic patterns at many spatio-temporal scales. This biological-physical link is readily observed in the coastal ocean, where both physical and planktonic gradients tend to be steeper cross-shelf than along-shore (Richardson et al. 1980, Mackas 1984, Sabates 1990, McGowen 1993), and steeper vertically than horizontally (Ahlstrom 1959, Minami \& Tamaki 1980, Boehlert et al. 1985). Studies of continental shelf ichthyoplankton communities have frequently been limited to an examination of either horizontal or vertical patterns, due to the high temporal variability encountered when sampling large spatial scales. The high amount of unexplained spatial and temporal variability which characterises many such studies may be a reflection of

•E-mail:marsci@unsw.edu.au variability in the unexplored dimension (e.g. Richardson et al. 1980, Sabates 1990, Cowen et al. 1993, Doyle et al. 1993, Loeb et al. 1993). In particular, studies of horizontal patterns are likely to be confounded by under-sampling of the relatively steep physical/biological vertical gradients associated with the pycnocline (A.hlstrom 1959, Loeb 1980).

The coastline of southeastern Australia is subject to considerable horizontal and vertical hydrographic variability as a result of large scale $(10$ s of $\mathrm{km})$, short term (days) upwelling events (McClean-Padman \& Padman 1991). This dynamic coastal ocean is also a convergence zone of tropical and temperate waters and, as a result, hosts a diverse adult fish community of temperate and tropical species (Kuiter 1993). The influence of sporadic, short term upwelling events on the distribution of ichthyoplankton over the shelf is unknown, despite their significance to environmental and fisheries studies. This situation arises partly from the diffi- 


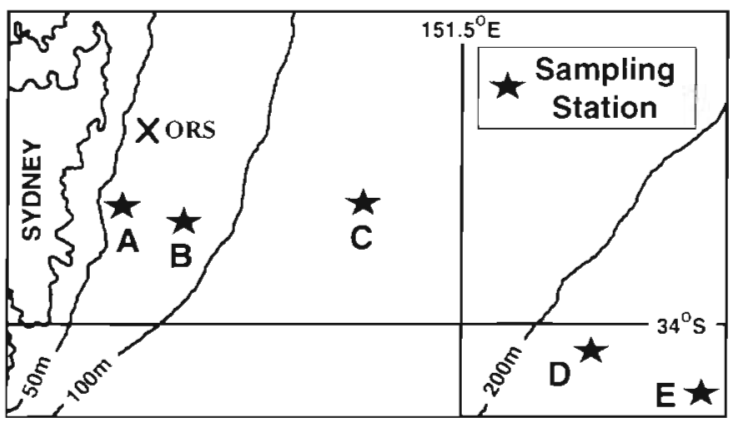

Fig. 1. Location of ichthyoplankton sampling stations (A to E) and Ocean Reference Station (ORS) across the Sydney continental shelf (Australia)

culties of sampling an unpredictable, large scale, short term oceanographic event.

Larval fish studies in the region have mostly been restricted to estuaries and the nearshore zone (Miskiewicz 1986, 1987. Steffe \& Pease 1988, Steffe 1989, Gray et al. 1992, Gray 1993, 1996a, b, Kingsford \& Suthers 1994). The only previous study of inner and outer shelf regions was restricted to surface observations and found that cross-shelf trends in neustonic ichthyoplankton reflected spawning patterns while, at smaller scales, ichthyoplankton variability reflected changes in near-surface hydrodynamics (Dempster et al. 1997). In surface and subsurface waters of the nearshore zone, consistent distributional trends occur with depth and distance from the shore, although high variability has been encountered in all directions (Gray 1993, 1996b). The vertical distribution of nearshore assemblages has not been related to hydrographic variability (thermocline depth), but rather to larval behaviour (Gray 1996a). Beyond the inner shelf, the composition and structure of subsurface Sydney shelf ichthyoplankton communities are not yet described. In addition, factors influencing both innner and outer shelf ichthyoplankton distributions are largely unknown, as is the case for many shelf regions.

The aim of the present study is to describe changes to shelf ichthyoplankton distributions which coincided with our observation of a coastal upwelling event off southeastern Australia. Based on observations made elsewhere, it was predicted that ichthyoplankton variability during this event would closely reflect hydrographic variability at the same spatio-temporal scales. Our approach differs from many previous investigations of shelf ichthyoplankton assemblages in that we have concurrently considered cross-shelf and vertical distributional patterns, and compared these with hydrological gradients in the same dimensions.

\section{METHODS}

Location and time of study. Data were collected in continental shelf waters adjacent to Sydney, on the southeast coast of Australia (Fig. 1). The shelf off Sydney is $40 \mathrm{~km}$ wide, and the shelf break occurs at a depth of approximately $200 \mathrm{~m}$. The dominant current in this region is the southward flowing East Australian Current (EAC) and associated eddies (Nilsson \& Cresswell 1981). Local wind stress and the passage of coastally trapped waves result in regular reversals of the shelf and slope flow. Compared to along-shore currents, cross-shelf currents are small, usually $<10 \mathrm{~cm} \mathrm{~s}^{-1}$ (Middleton, 1987). Density variability in the Sydney coastal ocean is primarily the result of changes in temperature (Griffin \& Middleton 1992). Short term temperature change in shelf waters may be dramatic, particularly in the nearshore zone, where it is associated with local wind events, but also across the shelf and slope region as a result of intrusions of both warm and cold EAC eddies (Griffin \& Middleton 1992, Gibbs et al. 1998). During summer, shelf waters generally exhibit strong temperature stratification, while during winter nearshore waters are often well mixed as a result of strong local winds and surface cooling (White \& Church 1986).

Data were collected during two 10 d cruises, January and April 1994, aboard the research vessel 'Franklin'. On both cruises, data were collected from 5 stations along a cross-shelf transect. The transect began $2.7 \mathrm{~km}$ offshore and ended $40 \mathrm{~km}$ from the coast. Plankton sampling Stations $A, B$ and C were within shelf waters (bottom depths less than $150 \mathrm{~m}$ ). Stn D was at the shelf break (bottom depth $250 \mathrm{~m}$ ), and Stn E occurred over the continental slope (bottom depth $600 \mathrm{~m}$. Fig. 1, Table 1).

Table 1. Location, bathymetry and depth interval for each ichthyoplankton sampling station

\begin{tabular}{|c|c|c|c|c|c|c|c|c|}
\hline \multirow[t]{2}{*}{ Stn } & \multirow[t]{2}{*}{ Latitude } & \multirow[t]{2}{*}{ Longitude } & \multirow{2}{*}{$\begin{array}{c}\text { Distance } \\
\text { offshore }(\mathrm{km})\end{array}$} & \multirow{2}{*}{$\begin{array}{c}\text { Bottom } \\
\text { depth }(m)\end{array}$} & \multicolumn{4}{|c|}{ Depth of sampling intervals (m) } \\
\hline & & & & & Net 1 & Net 2 & Net 3 & Surface \\
\hline A & $33^{\circ} 56.7^{\prime} \mathrm{S}$ & $151^{\circ} 17.5^{\prime} \mathrm{E}$ & 3 & 67 & $40-50$ & $30-40$ & $15-30$ & $0-1$ \\
\hline B & $33^{\circ} 57.5^{\prime} \mathrm{S}$ & $151^{\circ} 20.0^{\prime} \mathrm{E}$ & 7 & 83 & $60-70$ & $40-60$ & $15-40$ & $0-1$ \\
\hline $\mathrm{C}$ & $33^{\circ} 57.0^{\prime} \mathrm{S}$ & $151^{\circ} 26.5^{\prime} \mathrm{E}$ & 16 & 130 & $80-120$ & $40-80$ & $15-40$ & $0-1$ \\
\hline $\mathrm{D}$ & $34^{\circ} 00.0^{\prime} \mathrm{S}$ & $151^{\circ} 35.0^{\circ} \mathrm{E}$ & 33 & 250 & $80-120$ & $40-80$ & $15-40$ & $0-1$ \\
\hline E & $34^{\circ} 02.5^{\prime} \mathrm{S}$ & $151^{\circ} 40.0^{\prime} \mathrm{E}$ & 40 & 600 & $80-120$ & $40-80$ & $15-40$ & $0-1$ \\
\hline
\end{tabular}


Plankton was collected on 22, 23 and 25 January and on the 5, 6, 7 and 8 April. Some locations were not sampled on 7 April due to bad weather. Plankton was collected at night between 20:30 and 05:00 h in January, and 19:00 and 06:00 $\mathrm{h}$ in April. Sunset and sunrise were at approximately 20:00 and 06:00 h in January, and 17:45 and 06:00 $\mathrm{h}$ in April, respectively.

Collection and processing of samples. Surface plankton samples were collected using a $75 \times 75 \mathrm{~cm}$ square mouth net $(330 \mu \mathrm{m}$ mesh) fitted with a General Oceanics flow meter. Two surface hauls, each of $6 \mathrm{~min}$ duration, were conducted at each station. Near-surface temperature and salinity were recorded by shipboard instruments at a depth of $4 \mathrm{~m}$.

Subsurface plankton samples were collected by a multiple, opening and closing net (an 'EZ net') with a square mouth of $1 \mathrm{~m}^{2}$ and mesh size of $330 \mu \mathrm{m}$. The net was fitted with temperature, conductivity and depth sensors and 2 General Oceanics flow metersone inside and one outside the net mouth. Real time data were communicated to an operator onboard ship who electronically triggered each net release. Three depth strata were sampled at each station, and actual sampling depths varied according to water depth at each station (Table 1). Subsurface haul durations were $10 \mathrm{~min}$ and obliquely sampled each depth stratum.

All plankton samples were immediately placed into seawater and 5 to $10 \%$ formaldehyde. Fish were removed from samples between 1 and 24 mo after collection, counted and identified to the lowest possible taxon and then stored in 95\% ethanol. Results from surface sampling have been discussed in a previous paper by Dempster et al. (1997), but have been included here for comparison.

Nearshore wind and current data were obtained from the Ocean Reference Station (ORS), a permanent facility operated by Australian Water Technologies Ensight. The ORS records wind velocity and direction $5 \mathrm{~m}$ above the sea surface, and has current meters positioned at depths of 17 and $50 \mathrm{~m}$. Water depth at this location is $65 \mathrm{~m}$.

During daylight hours, a Neil-Brown CTD, with Turner fluorometer, was deployed along the sampling transect to provide additional cross-shelf hydrographic data (Gibbs et al. 1998). Fluorescence was uncalibrated, and measured as a percentage of full scale on the instrument.

Analysis. Composite cross-shelf temperature profiles from the EZ net CTD, over which ichthyoplankton abundance data were superimposed, were created for each monthly sampling.

The raw catches of total ichthyoplankton and of individual taxa were tabulated and then standardised to number of larvae per $100 \mathrm{~m}^{3}$. Standardised data were used in all analyses. Mean density of total ichthyoplankton, mean number of ichthyoplankton families and mean densities of individual taxa were calculated for the 3 or $4 \mathrm{~d}$ of sampling at each sampling location during each sampling month.

Total ichthyoplankton density, number of families and densities of some individual taxa were illustrated for each sampling month. Taxa representative of a range of depth distributions were selected on the basis of their relative abundance and our ability to identify them to species. We could not, however, identify mesopelagic taxa to species. Local notosudids and melamphaeids are probably each represented by a single species (Scopelosaurus meadi and Melamphaes sp., Gomon et al. 1994) and are some of the few abundant, deeply distributed taxa. Myctophidae is a speciose family, but is a useful tracer of oceanic water at this taxonomic level (Cowen et al. 1993).

Similarities between average larval assemblages at each sampling location were analysed by multivariate analyses. Mean ichthyoplankton family abundances were fourth root transformed to enhance the contribution of less abundant taxa. Excluded from this analysis were those families which did not occur during both sampling times or contributed $<1 \%$ to total abundance. As total larval densities differed by an order of magnitude between months, data were standardised to allow a comparison of sampling times. A Bray-Curtis similarity matrix was generated from this data (Bray \& Curtis, 1957) and similarities between assemblages were graphically represented by non-metric multidimensional scaling (MDS, Clarke 1993).

Detalls of analysis of wind data may be found in Dempster et al. (1997).

\section{RESULTS}

\section{Physical data and fluorescence}

A southerly wind event (downwelling favourable) coincided with the commencement of sampling in January (Fig. 2). Also at this time, encroachment over the slope by a warm-core eddy produced shoreward, interior, Ekman transport over most of the shelf (Smith et al. 1999). A period of northeasterly winds (upwelling favourable) coincided with sampling in April (Fig. 2). The warm-core eddy was no longer adjacent to Sydney in April. Average, cross-shelf, current velocity between 4 and 6 April was approximately $0.02 \mathrm{~m} \mathrm{~s}^{-1}$ (offshore) at the ORS top current meter and approximately zero at the bottom current meter (M. Gibbs unpubl. data).

Highest chlorophyll concentrations over the shelf were repeatedly observed immediately below the 


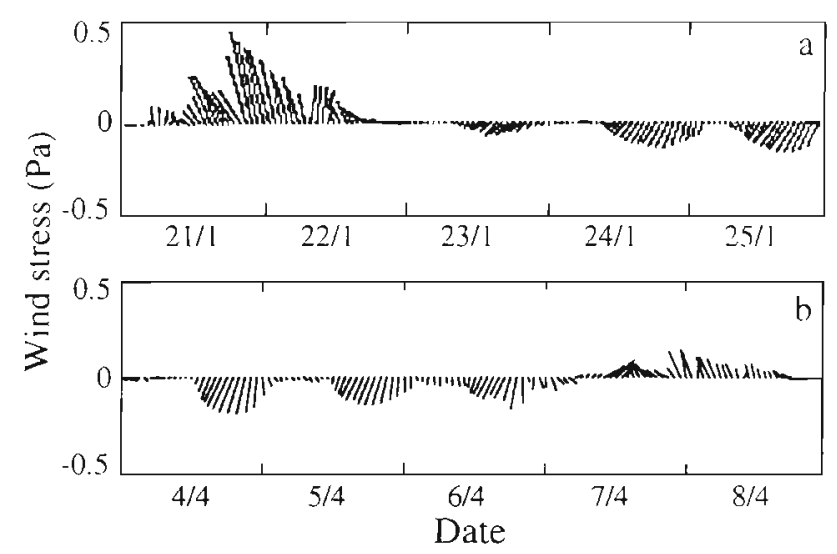

Fig. 2. Vector stick plots of hourly wind stresses at ORS from (a) 21 to 25 January and (b) 4 to 8 April 1994. (Vector sticks point in the direction in which wind was blowing)

mixed layer, at depths corresponding to the region of the upper thermocline, and changes in thermocline position corresponded to changes in the location of maximum fluorescence during each sampling period. This relationship is illustrated for 22 January (Fig. 3a, b).

The average cross-shelf temperature profile for the sampling period 22 to 26 January indicates a mixed layer $\left(>23^{\circ} \mathrm{C}\right)$ of between 20 and $40 \mathrm{~m}$ depth was overlying a thermocline of approximately $50 \mathrm{~m}$ depth at each sampling station (Fig. 4). Shallow waters of Stns D and $\mathrm{E}$ were slightly warmer $\left(>23.5^{\circ} \mathrm{C}\right)$, reflecting the near proximity of a warm-core eddy to the Sydney shelf (not shown).

The average cross-shelf temperature profile for the sampling period 5 to 8 April indicates hydrographic

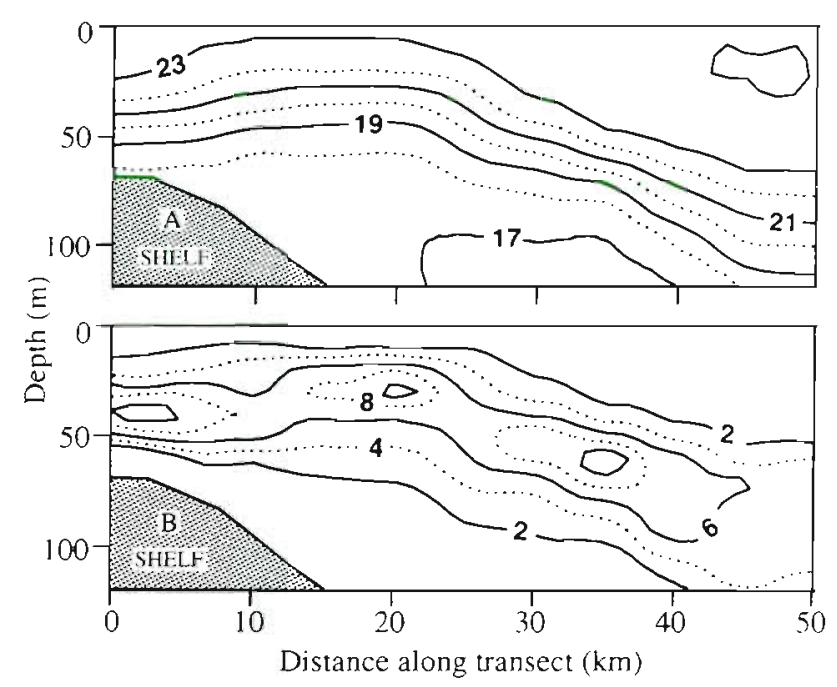

Fig. 3. Cross-shelf profiles of (a) temperature $\left({ }^{\circ} \mathrm{C}\right.$ ) and (b) fluorescence ( $\%$ of full scale on instrument) on 22 January 1994. illustrating the typical relationship between thermocline depth and depth of maximum fluorescence of Sydney conditions of the nearshore region were different to those of the outer shelf and slope during this second sampling period (Fig. 4). At Stns A and B, the mixed layer $\left(>23^{\circ} \mathrm{C}\right)$ was displaced by coastal upwelling of cooler shelf water. At Stns $C$ to $E$, a mixed layer of $40 \mathrm{~m}$ depth presented hydrographic conditions similar to those occurring over the shelf in January. The stratified region underlying the mixed layer in April (hereafter referred to as the 'thermocline') extended to a depth of approximately $130 \mathrm{~m}$ in offshore waters (not shown).

\section{Total larval abundance and diversity}

Total abundance and diversity of fish larvae captured in January was greater than in April. In 3 nights of sampling in January, 26866 larvae representing 99 families were captured. In 4 nights of sampling in April, 23915 larvae representing 95 families were captured (Table 2). Thus, the average ichthyoplankton catch per night in January was approximately 1.5 times higher than it was in April.

In January, approximately $75 \%$ of the total catch was comprised of 4 families-Myctophidae, Carangidae, Gonostomatidae and Clupeidae. In April, 12 taxa contributed $75 \%$ of the total catch-Myctophidae, Gonorhynchus greyi, Serranidae, Centroberyx affinis, leptocephali larvae, Scorpaenidae, Carangidae, Gonostomatidae, Callionymidae, Sillaginidae, Platycephalidae and Cepolidae (Table 2). In January (and April), $80 \%(90 \%)$ of carangids captured were Trachurus novaezelandiae, $66 \%(64 \%)$ of gonostomatids were Cyclothone spp. and $75 \%(64 \%)$ of sillaginids were Sillago flindersi (Table 3 ). The composition of the clupeid catch varied between months, being 65 and $32 \%$ Hyperlophus vittatus and Sardinops neopilchardus, respectively, in January and 28 and $58 \% \mathrm{H}$. vittatus and Etrumeus teres, respectively, in April. In other abundant families, either no single species was dominant or individuals were too small to be identified beyond the family level. Most larvae captured during the study were at a preflexion or flexion stage of development, with few postflexion individuals encountered.

The average number of ichthyoplankton families per sample decreased with distance from shore in January but increased with distance from shore in April (Fig. $4 \mathrm{a}, \mathrm{b}$ ). The number of families per sample ranged between 5 and 41 in January, and 0 and 44 in April. In both months, the number of families encountered was relatively low at the surface and in deep samples, and tended to be highest in shallow and middle depth samples. Shallow and middle sampling depths in both months corresponded to regions within the mixed layer and thermocline. 
Highest densities of ichthyoplankton occurred at either end of the sampling transect in January (Fig. 4c) Larval densities during January ranged between 8 and 3180 larvae $100 \mathrm{~m}^{-3}$. In April, average densities were much lower, ranging between 0 and 141 larvae $100 \mathrm{~m}^{-3}$, and densities increased with increasing distance from shore (Fig. 4d). Ichthyoplankton density at the surface and at the deepest locations was low in both months, except at Stn $E$ in April, due to the presence of relatively high numbers of Gonorhynchus greyi in surface waters at this time (see Fig. 6f). Most of the cross-shelf variability in larval density occurred at shallow and middle sampling depths.

Changes in larval densities corresponded to changes in the depth of the mixed layer. In January, shallow depth samples contained highest densities of larvae at all stations across the shelf (Fig. 4c). These shallow samples were taken primarily from within mixed layer water, at both inshore and offshore stations. In April, the depth of the mixed layer decreased at inshore stations such that all nearshore subsurface sampling was beneath the mixed layer (Fig. 4d). Nearshore larval densities were relatively low at all sampling depths in April. In contrast, the depth of the mixed layer increased slightly at offshore stations, which corresponded to an increase in larval density at middle sample depths, relative to densities at other depths.

\section{Distributions of individual taxa}

Most of the abundant taxa encountered during the study exhibited a change in cross-shelf distribution between sampling times. In particular, much of the between-month variability in total ichthyoplankton density and in the distribution of ichthyoplankton families was related to large between-month changes in the distribution of shelf-spawned taxa. Some shelfspawned taxa, which had been abundant in the nearshore zone during January, were largely absent from all stations in April (e.g. clupeids and engraulids, Table 2). Of the shelf-spawned taxa which occurred in both months, many were abundant at inshore stations during January, but at offshore stations during April (e.g. Centroberyx affinis, Chromis hypsilepsis and Arripis trutta, Table 2, Fig. 5). Larvae which were abundant at offshore stations in January were predominently mesopelagic (not shelf-spawned) and were again encountered in the offshore region during April (e.g. myctophids, Table 2, Fig. 6).

In January, the larvae of Centroberyx affinis, Chromis hypsilepsis and Arripis trutta were abundant at inshore Stns A to C, particularly in samples from within the mixed layer and upper thermocline (Fig. $5 \mathrm{a}-\mathrm{C}$ ). In
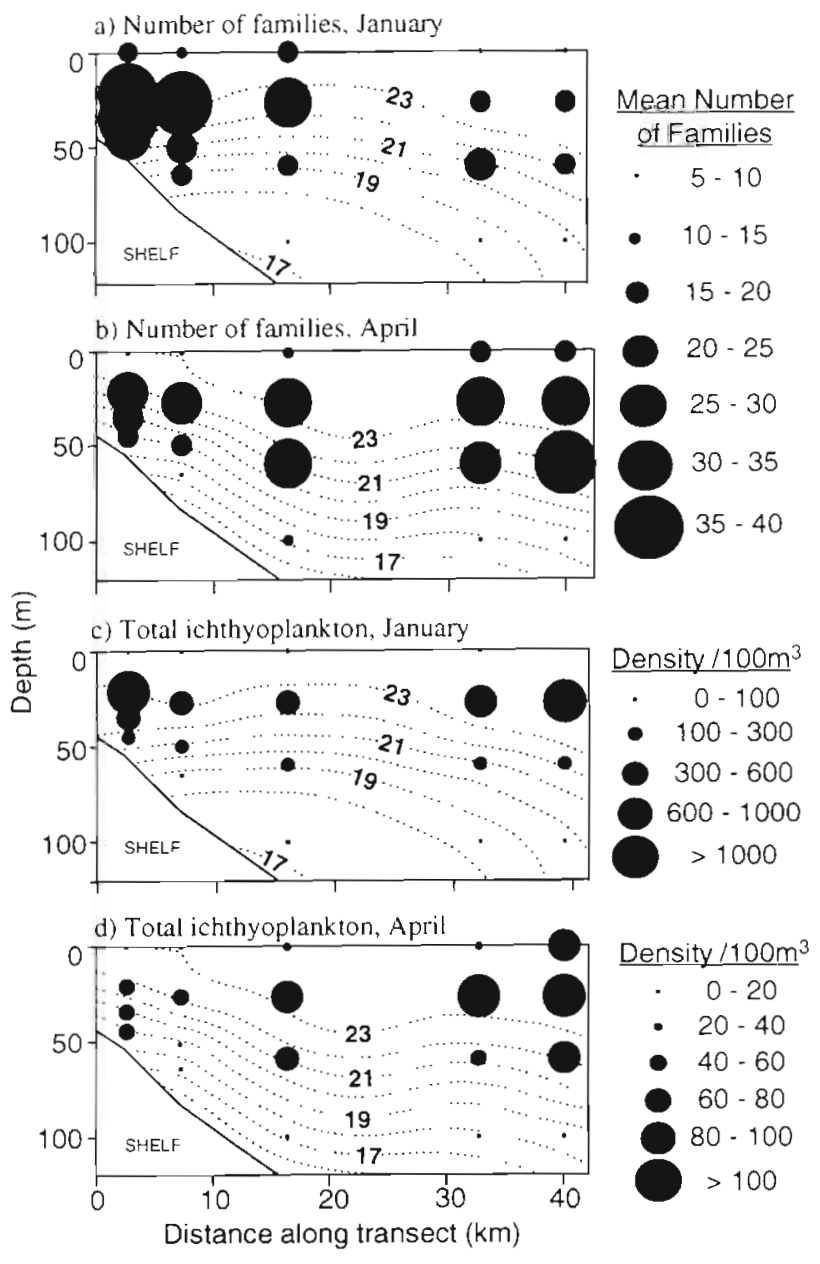

Fig. 4. Mean number of families caught at night in (a) January and (b) April 1994, and mean density of total ichthyoplankton in (c) January and (d) April 1994. Circle size is proportional to mean number of families (or ichthyoplankton density) at each sampling location and circles are centred in the middle of each sampling depth interval. Isotherms indicate average temperature profile during each sampling period

April, however, these larvae were most abundant at offshore Stns $C$ to $E$, again occurring within the mixed layer and upper thermocline (Fig. $5 d$-f). This represented an offshore shift in the location of maximum density of these larvae.

An offshore shift in maximum density was also observed in taxa which were already abundant at offshore stations in January. The larvae of Gonorhynchus greyi and myctophids were abundant in surface/mixed layer and mixed layer/upper thermocline samples, respectively, across the shelf and slope in January, although tending to be most abundant offshore at Stns D and E (Fig. 6a, b). In April, these larvae were again most abundant offshore, now at Stn $E$, but were present in relatively low densities at inshore Stns A and B (Fig. 6e, f). 
Table 2. Summary of total raw (non-standardised) catch of fish larvae caught across the Sydney shelf in January and April 1994 Listed is contribution (\%) of each family to the total monthly catch of larvae and a monthly ranking in order of decreasing contribution to total monthly catch. Refer to Table 3 for specific details of families containing several identified species. Classification follows Eschmeyer (1990). - no larvae

\begin{tabular}{|c|c|c|c|c|c|c|}
\hline \multirow[t]{2}{*}{ Order } & \multirow[t]{2}{*}{ Family } & \multirow[t]{2}{*}{ Specific } & \multicolumn{2}{|c|}{$\begin{array}{l}\text { Contribution of family } \\
\text { to total abundance }\end{array}$} & \multicolumn{2}{|c|}{$\begin{array}{l}\text { Abundance } \\
\text { ranking }\end{array}$} \\
\hline & & & Jan & Apr & Jan & Apr \\
\hline Anguilliformes & Leptocephali & & 1.63 & 6.77 & 9 & 5 \\
\hline Clupeiformes & $\begin{array}{l}\text { Clupeidae } \\
\text { Engraulidae }\end{array}$ & $\begin{array}{l}\text { (See Table } 3 \text { ) } \\
\text { Engraulis australis }\end{array}$ & $\begin{array}{l}5.24 \\
1.38\end{array}$ & $\begin{array}{l}0.29 \\
0.15\end{array}$ & $\begin{array}{r}4 \\
10\end{array}$ & $\begin{array}{l}33 \\
41\end{array}$ \\
\hline Gonorhynchiformes & Gonorhynchidae & Gonorhynchus greyi & 0.16 & 13.52 & 30 & 2 \\
\hline Salmoniformes & $\begin{array}{l}\text { Argentinidae } \\
\text { Bathylagidae }\end{array}$ & Bathylagus spp. & $\begin{array}{c}0.04 \\
-\end{array}$ & $\begin{array}{l}0.16 \\
0.02\end{array}$ & 56 & $\begin{array}{l}38 \\
71\end{array}$ \\
\hline Stomiiformes & $\begin{array}{l}\text { Gonostomatidae } \\
\text { Stomidae } \\
\text { Astronesthidae } \\
\text { Melanostomiitidae } \\
\text { Idiacanthidae }\end{array}$ & $\begin{array}{l}\text { (See Table 3) } \\
\text { Stomias spp. } \\
\text { Idiacanthus spp. }\end{array}$ & $\begin{array}{c}10.57 \\
- \\
0.01 \\
0.05 \\
-\end{array}$ & $\begin{array}{r}3.12 \\
<0.01 \\
0.09 \\
0.06 \\
<0.01\end{array}$ & $\begin{array}{c}3 \\
- \\
81 \\
52 \\
-\end{array}$ & $\begin{array}{r}8 \\
89 \\
48 \\
55 \\
90\end{array}$ \\
\hline Aulopiformes & $\begin{array}{l}\text { Aulopidae } \\
\text { Notosudidae } \\
\text { Synodontidae } \\
\text { Evermannellidae } \\
\text { Paralepididae } \\
\text { Chloropthalmidae } \\
\text { Scopelarchidae }\end{array}$ & $\begin{array}{l}\text { Aulopus spp. } \\
\text { Scopelosaurus spp. } \\
\text { Synodus spp. } \\
\text { (See Table 3) } \\
\text { Chloropthalmus spp. }\end{array}$ & $\begin{array}{r}0.07 \\
0.05 \\
0.52 \\
0.01 \\
0.36 \\
<0.01 \\
0.01\end{array}$ & $\begin{array}{c}1.02 \\
0.29 \\
0.20 \\
<0.01 \\
0.11 \\
- \\
-\end{array}$ & $\begin{array}{l}45 \\
50 \\
15 \\
82 \\
19 \\
93 \\
83\end{array}$ & $\begin{array}{l}20 \\
34 \\
36 \\
91 \\
42 \\
- \\
-\end{array}$ \\
\hline Myctophiformes & Myctophidae & & 31.09 & 16.47 & 1 & 1 \\
\hline Gadiformes & $\begin{array}{l}\text { Bregmacerotidae } \\
\text { Moridae } \\
\text { Merlucciidae } \\
\text { Gadidae }\end{array}$ & & $\begin{array}{l}0.10 \\
0.14 \\
0.01 \\
0.02\end{array}$ & $\begin{array}{l}0.10 \\
0.28 \\
0.54 \\
-\end{array}$ & $\begin{array}{l}41 \\
36 \\
84 \\
74\end{array}$ & $\begin{array}{c}44 \\
35 \\
24 \\
-\end{array}$ \\
\hline Ophidiiformes & $\begin{array}{l}\text { Ophidiidae } \\
\text { Carapidae }\end{array}$ & (See Table 3) & $\begin{array}{l}0.01 \\
0.02\end{array}$ & $\begin{array}{l}0.05 \\
0.16\end{array}$ & $\begin{array}{l}75 \\
69\end{array}$ & $\begin{array}{l}57 \\
39\end{array}$ \\
\hline Lophiiformes & $\begin{array}{l}\text { Antennariidae } \\
\text { Ceratiidae }\end{array}$ & & $\begin{array}{l}0.01 \\
0.05\end{array}$ & $\begin{array}{l}0.02 \\
0.20\end{array}$ & $\begin{array}{l}76 \\
51\end{array}$ & $\begin{array}{l}74 \\
37\end{array}$ \\
\hline Gobiesociformes & Gobiesocidae & (See Table 3) & 0.13 & 0.01 & 38 & 88 \\
\hline Lampridiformes & Trachipteridae & & 0.03 & 0.02 & 65 & 75 \\
\hline Beloniformes & $\begin{array}{l}\text { Exocoetidae } \\
\text { Bellonidae } \\
\text { Scomberesocidae }\end{array}$ & Scomberesox saurus & $\begin{array}{l}0.01 \\
- \\
0.04\end{array}$ & $\begin{array}{r}0.01 \\
<0.01 \\
0.01\end{array}$ & $\begin{array}{r}85 \\
- \\
57\end{array}$ & $\begin{array}{l}82 \\
92 \\
83\end{array}$ \\
\hline Beryciformes & $\begin{array}{l}\text { Trachichthyidae } \\
\text { Berycidae } \\
\text { Holocentridae } \\
\text { Melamphaeidae } \\
\text { Unidentified }\end{array}$ & Centroberyx affinis & $\begin{array}{r}0.04 \\
2.80 \\
0.01 \\
0.04 \\
<0.01\end{array}$ & $\begin{array}{c}0.07 \\
8.80 \\
- \\
0.36 \\
-\end{array}$ & $\begin{array}{r}58 \\
5 \\
88 \\
59 \\
94\end{array}$ & $\begin{array}{r}53 \\
4 \\
- \\
29 \\
-\end{array}$ \\
\hline Zeiformes & Caproidae & & $<0.01$ & 0.08 & 95 & 51 \\
\hline Syngnathiformes & $\begin{array}{l}\text { Macroramphosidae } \\
\text { Fistularidae } \\
\text { Syngnathidae }\end{array}$ & $\begin{array}{l}\text { Macroramphosus scolopax } \\
\text { Fistularia spp. }\end{array}$ & $\begin{array}{c}0.02 \\
0.01 \\
-\end{array}$ & $\begin{array}{r}1.95 \\
- \\
<0.01\end{array}$ & $\begin{array}{c}70 \\
86 \\
-\end{array}$ & $\begin{array}{c}14 \\
- \\
93\end{array}$ \\
\hline Scorpaeniformes & $\begin{array}{l}\text { Scorpaenidae } \\
\text { Triglidae } \\
\text { Platycephalidae } \\
\text { Hoplichthyidae } \\
\text { Dactylopteridae }\end{array}$ & $\begin{array}{l}\text { (See Table 3) } \\
\text { Hoplichthys spp. }\end{array}$ & $\begin{array}{l}0.42 \\
0.73 \\
2.22 \\
- \\
0.04\end{array}$ & $\begin{array}{r}4.14 \\
0.40 \\
2.23 \\
<0.01 \\
0.04\end{array}$ & $\begin{array}{r}17 \\
13 \\
8 \\
- \\
60\end{array}$ & $\begin{array}{r}6 \\
26 \\
11 \\
94 \\
63\end{array}$ \\
\hline Perciformes & $\begin{array}{l}\text { Howellidae } \\
\text { Ambassidae } \\
\text { Acropomatidae } \\
\text { Serranidae } \\
\text { Pseudochromidae } \\
\text { Callanthiidae } \\
\text { Terapontidae } \\
\text { Apogonidae } \\
\text { Sillaginidae } \\
\text { Malacanthidae }\end{array}$ & $\begin{array}{l}\text { Callanthias spp. } \\
\text { Pelates sexlineatus } \\
\text { (See Table 3) } \\
\text { (See Table 3) }\end{array}$ & $\begin{array}{l}0.28 \\
0.15 \\
0.01 \\
0.04 \\
- \\
- \\
0.01 \\
0.20 \\
2.40 \\
-\end{array}$ & $\begin{array}{l}0.11 \\
0.02 \\
0.02 \\
9.14 \\
0.01 \\
0.08 \\
0.03 \\
0.46 \\
2.63 \\
0.06\end{array}$ & $\begin{array}{c}21 \\
33 \\
90 \\
61 \\
- \\
- \\
89 \\
27 \\
7 \\
-\end{array}$ & $\begin{array}{r}43 \\
76 \\
77 \\
3 \\
80 \\
49 \\
65 \\
25 \\
10 \\
56\end{array}$ \\
\hline
\end{tabular}


Table 2 (continued)

\begin{tabular}{|c|c|c|c|c|c|c|}
\hline \multirow[t]{2}{*}{ Order } & \multirow[t]{2}{*}{ Family } & \multirow[t]{2}{*}{ Specific } & \multicolumn{2}{|c|}{$\begin{array}{l}\text { Contribution of family } \\
\text { to total abundance }\end{array}$} & \multicolumn{2}{|c|}{$\begin{array}{c}\text { Abundance } \\
\text { ranking }\end{array}$} \\
\hline & & & Jan & Apr & Jan & Apr \\
\hline \multirow{48}{*}{$\begin{array}{l}\text { Perciformes } \\
\text { (continued) }\end{array}$} & Carangidae & (See Table 3) & 26.80 & 3.81 & 2 & 7 \\
\hline & Coryphaenidae & \multirow[t]{2}{*}{ Coryphaena spp. } & 0.09 & $<0.01$ & 43 & 95 \\
\hline & Bramidae & & 0.01 & 0.01 & 77 & 84 \\
\hline & Arripidae & \multirow{2}{*}{ Arripis trutta } & 0.18 & 0.30 & 29 & 32 \\
\hline & Lutjanidae & & 0.02 & - & 71 & - \\
\hline & Gerreidae & \multirow{2}{*}{ Gerres spp. } & 0.39 & 0.03 & 18 & 67 \\
\hline & Haemulidae & & - & 0.08 & - & 52 \\
\hline & Sparidae & \multirow{6}{*}{ (See Table 3) } & 0.05 & 0.34 & 53 & 30 \\
\hline & Lethrinidae & & 0.01 & - & 91 & - \\
\hline & Nemipteridae & & 0.01 & 0.01 & 78 & 79 \\
\hline & Sciaenidae & & 0.22 & 0.10 & 25 & 45 \\
\hline & Mullidae & & 0.25 & 0.82 & 22 & 22 \\
\hline & Pempheridae & & 0.14 & 0.03 & 34 & 66 \\
\hline & Kyphosidae & \multirow{2}{*}{ Kyphosus spp. } & 0.15 & 0.04 & 31 & 61 \\
\hline & Scorpididae & & 0.07 & 0.03 & 46 & 68 \\
\hline & Girellidae & Girella spp. & 0.15 & - & 32 & - \\
\hline & Monodactylidae & \multirow[t]{2}{*}{ Schuetta spp. } & 0.19 & 0.05 & 28 & 58 \\
\hline & Chaetodontidae & & 0.01 & 0.01 & 92 & 78 \\
\hline & Pomacentridae & \multirow[t]{12}{*}{ (See Table 3) } & 2.55 & 1.41 & 6 & 16 \\
\hline & Cirrhitidae & & 0.02 & - & 72 & - \\
\hline & Aplodactylidae & & $<0.01$ & - & 96 & - \\
\hline & Cheilodactylidae & & $<0.01$ & 1.00 & 97 & 21 \\
\hline & Cepolidae & & 0.23 & 2.11 & 24 & 12 \\
\hline & Mugilidae & & 0.22 & 0.39 & 26 & 27 \\
\hline & Labridae & & 0.99 & 0.74 & 12 & 23 \\
\hline & Odacidae & & $<0.01$ & 0.16 & 98 & 40 \\
\hline & Scaridae & & 0.06 & 0.08 & 47 & 50 \\
\hline & Chiasmodontidae & & 0.06 & 0.06 & 48 & 54 \\
\hline & Champsodontidae & & 0.01 & 0.09 & 87 & 47 \\
\hline & Uranoscopidae & & $<0.01$ & 0.01 & 99 & 81 \\
\hline & Creedidae & \multirow{3}{*}{ (See Table 3) } & 0.31 & 1.35 & 20 & 17 \\
\hline & Leptoscopidae & & $<0.01$ & - & 103 & - \\
\hline & Percophidae & & 0.06 & 2.10 & 49 & 13 \\
\hline & Pinguipedidae & Parapercis spp. & 0.03 & 1.31 & 64 & 19 \\
\hline & Tripterygidae & & $<0.01$ & - & 101 & - \\
\hline & Blennidae & & 0.04 & 0.04 & 55 & 64 \\
\hline & Callionymidae & & 0.44 & 3.02 & 16 & 9 \\
\hline & Schindleriidae & Schindleria spp. & 0.05 & 0.01 & 54 & 86 \\
\hline & Gobiidae & & 0.69 & 1.33 & 14 & 18 \\
\hline & Microdesmidae & & $<0.01$ & - & 100 & - \\
\hline & Siganidae & & - & 0.01 & - & 85 \\
\hline & Acanthuridae & & 0.03 & - & 63 & - \\
\hline & Sphyraenidae & Sphyraena spp. & 0.03 & 0.05 & 66 & 59 \\
\hline & Gempylidae & & 0.04 & 0.03 & 62 & 69 \\
\hline & Trichiuridae & Lepidopus spp. & $<0.01$ & 0.02 & 102 & 72 \\
\hline & Scombridae & & 0.11 & 0.05 & 40 & 60 \\
\hline & Nomeidae & & 0.09 & 0.02 & 42 & 73 \\
\hline & Tetragonuridae & Tetragonurus spp. & 0.14 & 0.01 & 35 & 87 \\
\hline Pleuronectiformes & Paralichthyidae & & 0.25 & 0.39 & 23 & 28 \\
\hline & Bothidae & & 1.23 & 1.49 & 11 & 15 \\
\hline & Pleuronectidae & & 0.01 & 0.03 & 79 & 70 \\
\hline & Soleidae & & 0.02 & 0.10 & 73 & 46 \\
\hline & Cynoglossidae & & 0.13 & 0.34 & 39 & 31 \\
\hline & Unidentified & & 0.03 & - & 67 & - \\
\hline Tetraodontiformes & Monocanthidae & & 0.13 & - & 37 & - \\
\hline & Ostraciidae & & 0.03 & $<0.01$ & 68 & 96 \\
\hline & Tetraodontidae & & 0.07 & 0.04 & 44 & 62 \\
\hline & Diodontidae & & - & $<0.01$ & - & 97 \\
\hline & Unidentified & & 0.01 & - & 80 & - \\
\hline Unidentified & & & 1.90 & 2.27 & Not & nked \\
\hline Total ichthyoplan & $h: \operatorname{Jan}=26866 ; A$ & 5; $\mathrm{Jan}+\mathrm{Apr}=50$ & & & & \\
\hline
\end{tabular}


JANUARY

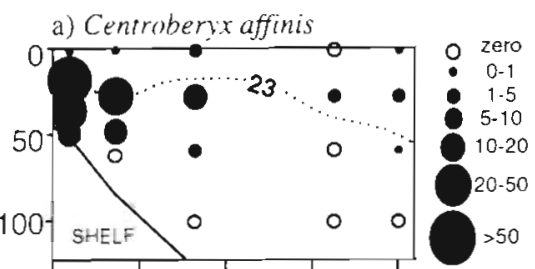

b) Chromis hypsilepsis
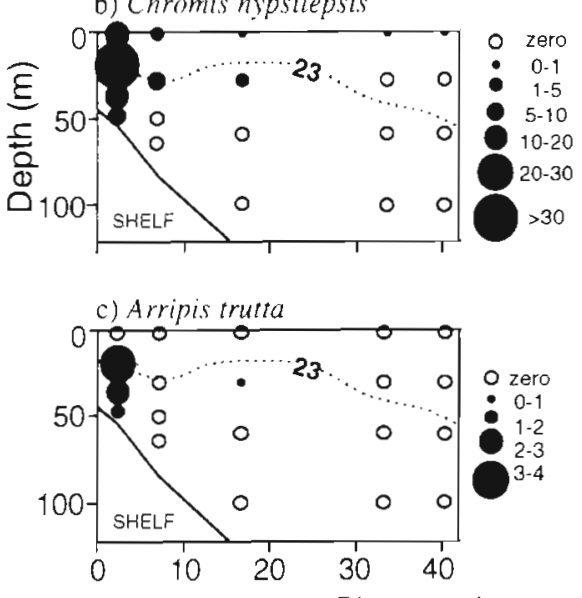

Distance along transect $(\mathrm{km})$

JANUARY
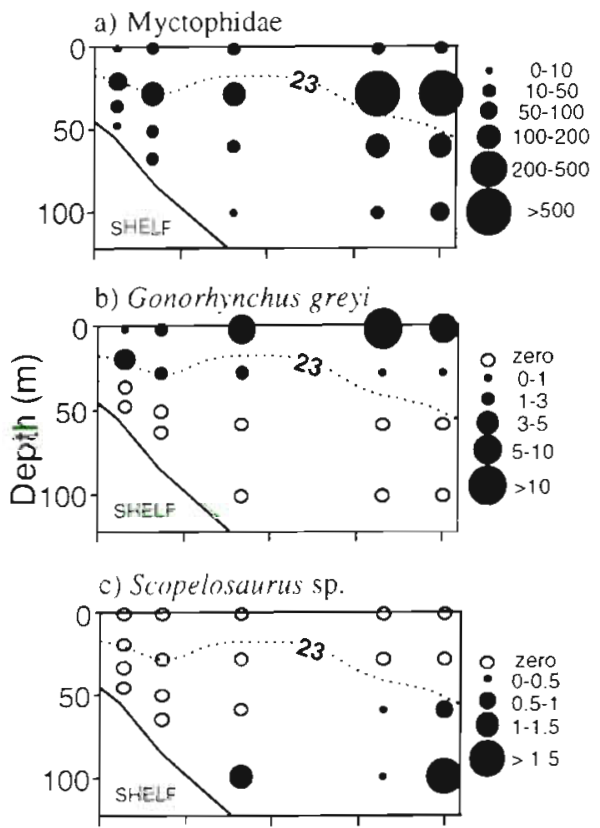

d) Melamphaes sp.

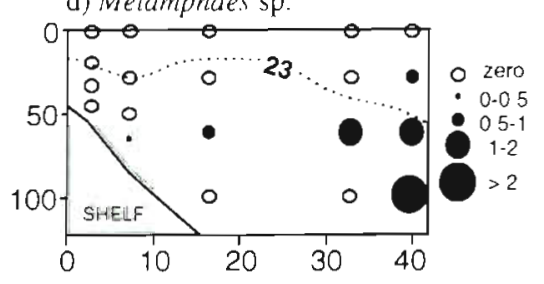

APRIL

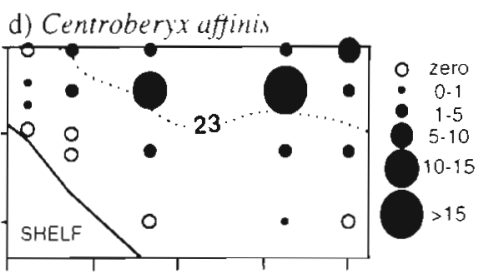

e) Chromis hypsilepsis
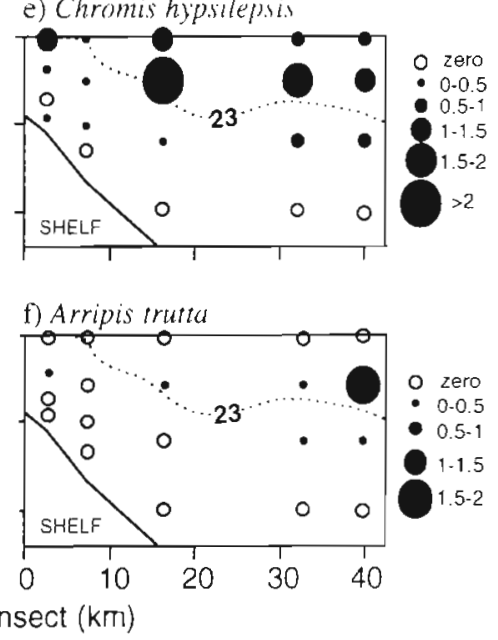

APRIL
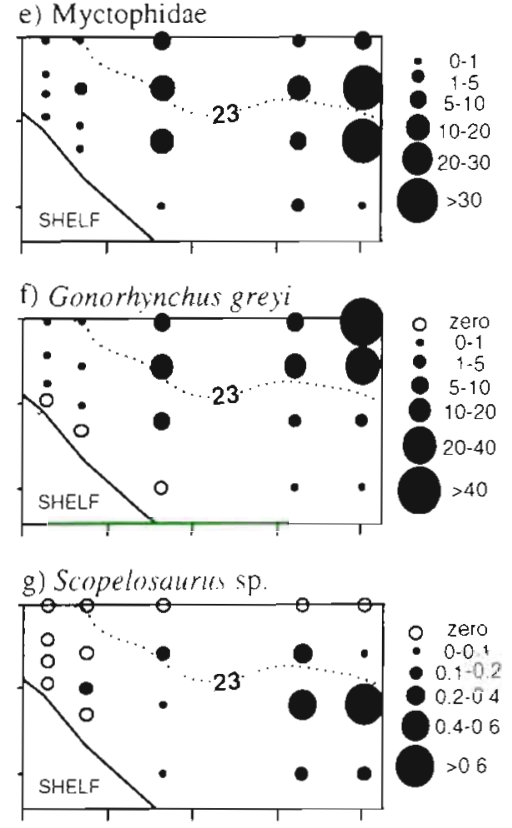

h) Melamphats sp.

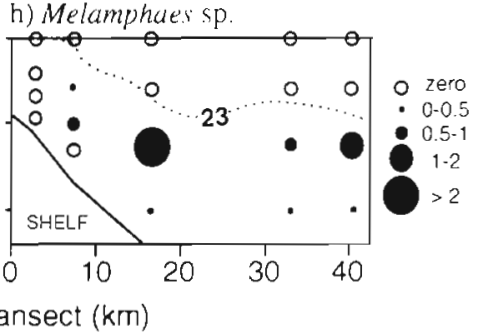

Fig. 5. Mean night-time densities of $\left(a_{1}\right.$ d) Centroberyx affinis, (b, e) Chromis hypsilepsis and (c, f) Arripis trutta in January and April 1994. Circle size is proportional to mean density at each sampling location and circles are centred in the middle of each sampling depth interval. $23^{\circ} \mathrm{C}$ isotherm indicates average depth of mixed layer during each sampling period

Fig. 6. Mean night-time densities of $\left(a_{2}\right.$ e) Myctophidae, (b, f) Gonorhynchus greyi, (c, g) Scopelosaurus sp. and (d, h) Melamphaes sp. in January and April 1994. Circle size is proportional to mean density at each sampling location and circles are centred in the middle of each sampling depth interval. $23^{\circ} \mathrm{C}$ isotherm indicates average depth of mixed layer during each sampling period 
Table 3. Catches of ichthyoplankton families consisting of several identified taxa. Listed is the specific contribution (\%) to the total monthly family catch. . Calculated from subsurface samples only

\begin{tabular}{|c|c|c|c|}
\hline \multirow[t]{2}{*}{ Family } & \multirow[t]{2}{*}{ Specific } & \multicolumn{2}{|c|}{$\begin{array}{l}\% \text { of family } \\
\text { abundance }\end{array}$} \\
\hline & & Jan & Apr \\
\hline \multirow[t]{4}{*}{ Clupeidae } & Hyperlophus vittatus & 65.3 & 28.4 \\
\hline & Sardinops neopilchardus & 32.3 & 11.9 \\
\hline & Etrumeus teres & 0.4 & 58.2 \\
\hline & Unidentified spp. & 2.0 & 1.5 \\
\hline \multirow[t]{5}{*}{ Gonostomatidae } & Cyclothone spp. & 66.0 & 64.5 \\
\hline & Diplophos spp. & 1.9 & 0.0 \\
\hline & Maurolicus spp. & 0.0 & 0.0 \\
\hline & Vinciguerria spp. & 0.3 & 0.0 \\
\hline & Unidentified spp. & 31.8 & 35.5 \\
\hline \multirow[t]{4}{*}{ Paralepididae } & Studis atrox & 4.1 & 0.0 \\
\hline & Notolepis spp. & 1.0 & 7.4 \\
\hline & Stemonosudis spp. & 1.0 & 0.0 \\
\hline & Unidentified spp. & 93.8 & 92.6 \\
\hline \multirow[t]{2}{*}{ Ophidiidae } & Genypterus blacodes & 33.3 & 45.5 \\
\hline & Unidentified spp. & 66.7 & 54.6 \\
\hline \multirow[t]{2}{*}{ Gobiesocidae } & Alabes spp. & 76.5 & 100.0 \\
\hline & Unidentified spp. & 23.5 & 0.0 \\
\hline \multirow[t]{4}{*}{ Scorpaenidae } & Neosebastes spp. & 13.9 & 3.8 \\
\hline & Centropogon australis & 11.9 & 1.8 \\
\hline & Helicolenis spp. & 0.0 & 0.1 \\
\hline & Unidentified spp. & 74.3 & 94.3 \\
\hline \multirow[t]{2}{*}{ Apogonidae } & Apogonops anomalus & 47.9 & 97.3 \\
\hline & Unidentified spp. & 52.1 & 2.7 \\
\hline \multirow[t]{2}{*}{ Sillaginidae } & Sillago flindersi & 74.6 & 63.7 \\
\hline & Sillago spp. & 25.4 & 36.3 \\
\hline \multirow[t]{4}{*}{ Carangidae } & Trachurus novaezelandiae & 80.3 & 90.5 \\
\hline & Pseudocarynx dentex & 19.5 & 7.4 \\
\hline & Seriola spp. & 0.0 & 1.5 \\
\hline & Unidentified spp. & 0.2 & 0.7 \\
\hline \multirow[t]{4}{*}{ Sparidae } & Rhabdosargus sárba & 8.3 & 53.1 \\
\hline & Acanthopagrus australis & 8.3 & 25.9 \\
\hline & Pagrus auratus & 50.0 & 19.8 \\
\hline & Unidentified spp. & 33.3 & 1.2 \\
\hline \multirow[t]{2}{*}{ Pomacentridae } & Chromis hypsilepsis & 93.4 & 87.6 \\
\hline & Unidentified spp. & 6.6 & 12.4 \\
\hline \multirow[t]{2}{*}{ Creedidae } & Creedia haswelli & 90.2 & 100.0 \\
\hline & Unidentified spp. & 9.8 & 0.0 \\
\hline
\end{tabular}

The larvae of some more deeply distributed taxa underwent an onshore shift in the location of maximum density between sampling times. The distributions of Scopelosaurus sp. and Melamphaes sp. larvae were mostly restricted to deep water over the outer shelf and slope in January, but extended into the nearshore zone in April (Fig. 6c, d, g, h).

The inshore occurrence of these deeply distributed larvae, which were formerly restricted to the outer shelf, corresponded to the coastward intrusion of cold, deep, shelf water. Similarly, the disappearance in April of both shelf-spawned and mesopelagic larvae from shallow, nearshore waters corresponded to the offshore displacement of the nearshore mixed layer by upwelled water.

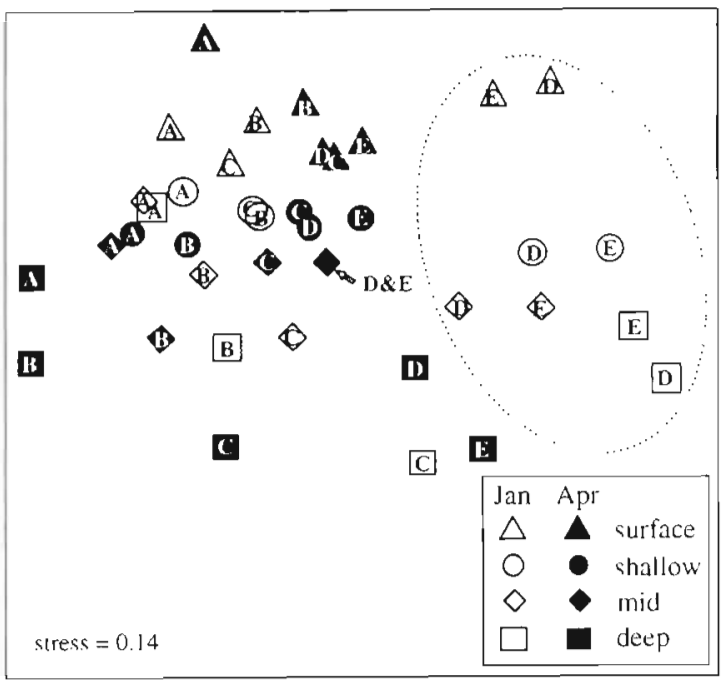

Fig. 7. Two dimensional, MDS ordination of Bray-Curtis similarities between average ichthyoplankton assemblages at each sampling location in January and April 1994. Each point within the ordination represents the average assemblage at each depth/station location in either January or April. Letters indicate stations. Data were standardised and 4 th root transformed; taxa excluded if not occurring in both months or if contributing $<1 \%$ of total abundance

\section{Similarities between ichthyoplankton assemblages}

The nearshore upwelling event during April coincided with changes to the distribution of ichthyoplankton assemblages across the shelf. The MDS ordination of average assemblages at each sampling location, from both sampling times, indicated that assemblages from Stns D and E in January (circled) are distinct from all other assemblages (Fig. 7). In April, assemblages sampled at D and E were similar to those sampled further inshore during both January and April. The dimensions of the ordination may be interpreted as depth (top-bottom) and distance from shore (left-right). On both sampling ocasions, surface assemblages are at the top of the ordination, deep are at the bottom, inshore are to the left, and offshore are to the right. The between-month shift in the positions of Stns $D$ and $E$ assemblages was to the left, suggesting the character of outer shelf and slope communities became more 'coastal' between April and January.

\section{DISCUSSION}

\section{Taxonomic diversity of the Sydney shelf}

The Sydney shelf ichthyoplankton community is taxonomically diverse. During 7 nights of sampling, 111 families (excluding leptocephali larvae) were col- 
lected, with up to 44 families collected by a single $10 \mathrm{~min}$ tow. Previous ichthyoplankton surveys of coastal and shelf regions elsewhere report lower diversity, e.g. 101 families in 33 yr of sampling off California (Moser et al. 1993, 1994), 100 families in $33 \mathrm{~d}$ in the Gulf of Mexico (Richards et al. 1993), 103 families in 1 yr off northwestern Australia (Young et al. 1986) and 99 families in 3 yr on the Australian Great Barrier Reef (Leis \& Goldman 1987). The high diversity may be due, in part, to the fact that the Sydney shelf is adjacent to a region of convergence between temperate and tropical waters and assemblages may have included fauna of both water types. The presence during this study of taxa such as scarids and fistulariids, which are usually associated with coral reefs (Leis \& Rennis 1983), indicates the southward advection of tropical species.

Warm-core eddies and meanders, associated with the EAC, have the potential to transport tropical organisms southward into temperate zones. The EAC originates in the Coral Sea and flows southward along the east Australian coast to approximately $32^{\circ} \mathrm{S}$, where it then turns eastward. In this region, several warmcore eddies may form each year and individual eddies may persist for over 12 mo (Nilsson \& Cresswell 1981). These eddies may continue moving southward and frequently encroach over the continental slope and shelf. For example, during the January sampling period, an intense warm-core eddy was present on the continental slope adjacent to Sydney. Previous ichthyoplankton surveys on the southeast Australian coast have encountered the larvae of tropical species in temperate waters (Miskiewicz 1989, Gray 1993) and juveniles of tropical species regularly recruit to temperate coastal habitats as far south as $35^{\circ} \mathrm{S}$, although survival of these individuals is generally restricted to the warmer months (Leadbitter \& Pollard 1987, Kuiter 1993). The transport of tropical species by warm currents and eddies into temperate habitats has been documented elsewhere, including Western Australia (Maxwell \& Cresswell 1981, Hutchins \& Pearce 1994) and northeastern America (Cowen et al. 1993). The subsequent mortality of such individuals suggests that larvae become entrained by chance and are transported passively within the warm water mass.

\section{Tracers of water movement}

The distribution of total ichthyoplankton abundance and diversity showed different cross-shelf trends in each month. In January, abundance was highest at either end of the sampling transect and diversity decreased with distance from shore. In April, both abundance and diversity increased with distance from shore. Changes in the distribution of shelf-spawned larvae account for much of this variability. Numerous taxa which had been very abundant within the inshore region in January either largely disappeared or were captured further offshore in April. Several processes, biological and physical, were responsible for these dramatic changes.

Firstly, a period of upwelling-favourable winds, and the subsequent offshore displacement of warm surface water, observed during April appeared to markedly alter the distribution of ichthyoplankton over the shelf. During both sampling periods, maximum ichthyoplankton density and taxonomic diversity occurred within the warm water of the mixed layer and the adjacent, cooler, stratified water of the upper thermocline. In the absence of an overlying mixed layer, such as occurred in the nearshore zone in April, relatively low ichthyoplankton density and diversity were associated with stratified water. This result suggests an association of numerous coastal and mesopelagic larvae with waters of the mixed layer. Upwelling-favourable winds observed in April appeared to displace both the mixed layer and its associated ichthyoplankton community offshore. At this scale, larvae appear as tracers of water movement over the shelf.

This result is complemented by between-month changes in the distribution of deeper larvae, such as Scopelosaurus sp. and Melamphaes sp. Just as coastal upwelling implies the offshore transport of surface water, it also implies the shoreward transport of deeper water. The distributions of these taxa moved shoreward between January and April, corresponding to the concurrent, shoreward movement of deeper water. Thus, these more deeply distributed larvae are also apparent tracers of water movement over the shelf.

Secondly, the general decline in the density of shelfspawned larvae between sampling periods and the near absence in April of taxa such as clupeids and engraulids, which had been abundant in January, probably reflect seasonal spawning patterns. Many local coastal species, including clupeids, engraulids, sillaginids, Centroberyx affinis and Arripis trutta, spawn during summer and the April sampling period probably coincided with the end of the spawning periods of these taxa (Kailola et al. 1993). In contrast to coastal fish, the reproductive cycles of many mesopelagic fish are weakly seasonal, or non-seasonal (Gjosæter \& Kawaguchi 1980, Olivar \& Beckley 1994), resulting in less pronounced seasonal variability in the composition of many offshore (mesopelagic) ichthyoplankton communities (Ahlstrom 1972, Loeb 1979, Doyle et al. 1993). The composition of offshore communities sampled by this study displayed limited between-month variability.

Further biological factors could have affected the observed change in distributions. For example, a shift 
in adult spawning location could result in differing larval distributions. The spawning location(s) of most species encountered in this study, including abundant larval species such as Centroberyx affinis, is not known. However, Arripis trutta spawns pelagic eggs in the nearshore zone along the southeast Australian coast (Kailola et al. 1993) and Chromis hypsilepsis lays demersal eggs in the nearshore zone (Kuiter 1993). Despite restricted and consistent spawning locations, larvae of these species underwent a major distributional shift between months, suggesting that spawning location was not a significant factor influencing distributional variability in these larvae.

The mechanism(s) by which planktonic larvae maintain their distributions is unclear. The results of the present study suggest that ichthyoplankton communities in the Sydney region may be modelled as passive tracers of water mass movement, but the processes leading to such distributions may be physical, behavioural, or a combination of both. The concurrent displacement of fish larvae and water could arise if larvae were drifting passively within their host water masses but could also arise through active behavioural responses to changes in hydrography. Oceanographic processes have the potential to retain or transport passive particles, and hence also larvae (Norcross \& Shaw 1984, Kingsford 1990, Sabates \& Maso 1992, Govoni \& Pietrafesa 1994), yet most ichthyoplankton are not completely passive particles. Swimming ability may be limited in young larvae, such as those encountered in this study (Miller et al. 1988), although buoyancy adjustment could allow considerable vertical and horizontal migration, even in very young larvae. Evidence from numerous studies suggests that plankton distributions are often defined by hydrodynamic boundaries but may be maintained by plankton behaviour. Many planktonic organisms appear capable of moving between water masses, and do so at certain times in their life history, but are equally capable of maintaining their distributions within the same water mass or frontal region, perhaps by using hydrological parameters as a guide (e.g. Sameoto 1984, Sinclair \& Iles 1985, Boucher et al. 1987). In addition, planktonic distributions do not always follow the predicted path of 'passive particles' and behavioural mechanisms must sometimes be invoked (Cowen et al. 1993, Wiafe \& Frid 1996). Thus, it may be appropriate to consider planktonic organisms as 'active' tracers. Their distributions frequently reflect hydrological boundaries, in the character of passive particles, but behavioural mechanisms may underlie such distributions. Determination of the exact nature of the mechanisms which influence larval distributions in the Sydney region requires sampling at a greater frequency and smaller spatial scale than that undertaken by the present study.

\section{Interface between mixed layer and thermocline}

Highest ichthyoplankton density and diversity were typically associated with the interface between the mixed layer and the thermocline over the Sydney shelf. Thermocline, or halocline, position frequently appears to regulate the vertical distribution of ichthyoplankton in coastal and oceanic waters (Ahlstrom 1959, Loeb 1980, Kendall \& Naplin 1981, Boehlert et al. 1985, Davis et al. 1990. Palomera 1991). Maximum chlorophyll concentrations were also observed adjacent to this interface, within the upper thermocline. The interface between the warm, mixed layer and the cooler thermocline may represent a region of optimum growth and feeding for many larvae.

In contrast to our results, Gray (1996a) concluded that variations in thermocline depth did not contribute to the structure of nearshore ichthyoplankton assemblages off Sydney, and that the vertical distribution of nearshore ichthyoplankton in months of water column stratification was similar to that in a month in which there was no stratification. Differing hydrodynamic regimes may account for such contrasting conclusions. Our study found that, when compared to conditions elsewhere over the shelf, the nearshore mixed layer and thermocline were often poorly defined and stratification of the nearshore water column was in a constant state of flux (changing daily). Stratification of the nearshore zone ( 0 to $5 \mathrm{~km}$ from shore) is primarily driven by, and rapidly responsive to, wind forcing, unlike regions further offshore, which are primarily driven by currents (Gibbs et al. 1998). Hydrodynamics in the nearshore zone are thus fundamentally different to those elsewhere over the shelf. It may be that the hydrodynamic instability of the nearshore zone inhibits the formation of ichthyoplankton distributions which are typical elsewhere over the shelf. Alternatively, the behavioural response of nearshore ichthyoplankton communities to hydrodynamic variability may be different to that of communities further offshore (Marliave 1986, Lavett Smith et al. 1987).

\section{Conclusions}

The response of ichthyoplankton to coastal upwelling, as presented here, is based on our observations of a single oceanographic event. The generality of the response in the Sydney region can only be cletermined by further sampling of future upwelling events. Unfortunately, the unpredictable and transient nature of many coastal processes, including upwelling, tends to limit the number of observations which can be made. However, similar ichthyoplankton responses to coastal upwelling have been seen elsewhere (e.g. 
Hamann et al. 1981), suggesting that the observations presented here may be typical.

Irregular, unpredictable and dramatic changes in coastal hydrography, such as that observed in April 1994, and the concurrent changes in ichthyoplankton distributions, may confound attempts to describe ichthyoplankton distributions in the coastal ocean. Indeed, previous ichthyoplankton studies in the Sydney region have encountered high biological variability at a range of temporal and spatial scales, which was not adequately explained by non-hydrological parameters such as sampling depth, distance from shore, ontogenetic changes in distribution and seasonal reproductive cycles (Gray et al. 1992, Gray 1993, 1996b). The results of the present study confirm the need for adequate physical data to complement biological sampling programmes. In the absence of hydrographic information, the distributional variability observed in this study would have been difficult to interpret. Further insights into the influence of physical forcings on ichthyoplankton distributions may be gained by the examination of among-night variation (Smith et al. 1999).

The results of this study indicate that the vertical structure of ichthyoplankton communities is influenced by the positioning of hydrographic boundaries, especially the interface between the mixed layer and the thermocline. Results also suggest horizontal structuring of assemblages, despite the absence of any obvious hydrographic gradient in this dimension. Specifically, the community associated with the mixed layer during January showed cross-shelf trends in taxonomic composition, which reflected general spawning locations. In the nearshore zone, shelfspawned taxa were dominant, whereas over the outer shelf and slope, mesopelagic taxa were dominant. However, while some mesopelagic larvae were also present in the nearshore zone, shelf-spawned taxa were largely absent from offshore regions during January. A similar pattern has been observed across the Spanish continental shelf, in association with a salinity front (Sabates \& Olivar 1996). The mechanism on the Sydney shelf which temporarily restricts the offshore distribution of coastal larvae, while allowing the shoreward movement of oceanic larvae, is not clear from this study and presents an area for future research.

Acknowledgements. Thanks to A. Miskiewicz for assistance with identification, M. Gibbs, J, Middleton, R. Lee and D. Rissik for useful discussions, J. Leis for reviewing an earlier draft, and anonymous reviewers for helpful criticism. We gratefully acknowledge the support provided by the captain and crew of the RV 'Franklin' This study was funded in part by the Australian Research Council and a University of N.S.W. Special Research Grant.

\section{LITERATURE CITED}

Ah.strom. E.H (1959) Vertical distribution of pelagic eggs and larvae off California and Baja California. Fish Bull US 60 . $107-146$

Ahlstrom EH (1972) Kinds and abundance of fish larvae in the eastern Pacific on the second multivessel Eastropac survey and observations on the annual cycle of larval abundance. Fish Bull US 70:1153-1242

Boehlert GW, Gadomski DM, Mundy BC (1985) Vertical distribution of ichthyoplankton off the Oregon coast in spring and summer months. Fish Bull 83:611-621

Boucher J, Ibanez F, Prieur L (1987) Daily and seasonal variations in the spatial distribution of zooplankton populations in relation to the physical structure in the Ligurian Sea Front. J Mar Res 45:133-173

Bray JR, Curtis JT (1957) An ordination of the upland forest communities of southern Wisconsin. Ecol Monogr 27: $325-349$

Clarke KR (1993) Non-parametric multivariate analysis of changes in community structure. Aust J Ecol 18:117-143

Cowen RK, Hare JA, Fahay MP (1993) Beyond hydrography: can physical processes explain larval fish assemblages within the middle Atlantic Bight? Bull Mar Sci 53:567-587

Davis TLO, Jenkins GP, Young JW (1990) Diel patterns of vertical distribution in larvae of southern bluefin Thunnus maccoyii, and other tuna in the East Indian Ocean. Mar Ecol Prog Ser 59:63-74

Dempster T, Gibbs MT, Rissik D, Suthers IM (1997) Beyond hydrography: daily ichthyoplankton variability and short term oceanographic events on the Sydney continental shelf. Cont Shelf Res 17:1461-1481

Doyle MJ, Morse WW. Kendall AW Jr (1993) A comparison of larval fish assemblages in the temperate zone of the northeast Pacific and northwest Atlantic oceans. Bull Mar Sci 53:588-644

Eschmeyer WN (1990) Catalog of the genera of recent fishes. California Academy of Sciences, San Francisco, p i-v, $1-697$

Gibbs MT, Middleton JH, Marchesiello (1998) Baroclinic response of Sydney shelf waters to local wind and deep ocean forcing. J Phys Oceanogr 28:178-190

Gjosæter J, Kawaguchi K (1980) A review of the world resources of mesopelagic fish. FAO Fish Tech Pap 193: $1-151$

Gomon MF, Glover JCM, Kuiter RH (1994) The fishes of Australia's south coast. State Print. Adelaide

Govoni JJ, Pietrafesa LJ (1994) Eulerian views of layered water currents, vertical distribution of some larval fishes, and inferred advective transport over the continental shelf off North Carolina, USA, in winter. Fish. Oceanogr 3 $120-132$

Gray CA (1993) Horizontal and vertical trends in the distributions of larval fishes in coastal waters off central New South Wales, Australia. Mar Biol 116:649-666

Gray CA (1996a) Do thermoclines explain the vertical distributions of larval fishes in the dynamic coastal waters of south-eastern Australia? Mar Freshw Res 47:183-190

Gray CA (1996b) Small-scale temporal variability in assemblages of larval fishes: implications for sampling. J Plankton Res 18:1643-1657

Gray CA, Otway NM, Laurenson FA, Miskiewicz AG, Pethebridge RL (1992) Distribution and abundance of marine fish larvae in relation to effluent plumes from sewage outfalls and depth of water. Mar Biol 113:549-559

Griffin DA, Middleton JH (1992) Upwelling and internal tides 
over the inner New South Wales continental shelf. J Geophys Res 97:14389-14405

Hamann I, John HC, Mittlestaedt E (1981) Hydrography and its effect on fish larvae in the Mauritanian upwelling area. Deep-Sea Res 28:561-575

Hutchins JB, Pearce AF (1994) Influence of the Leeuwin Current on recruitment of tropical reef fishes at Rottnest Island, Western Australia. Bull Mar Sci 54:245-255

Kailola P, Williams MJ, Stewart PC, Reichelt RE, McNee A, Greeve C (1993) Australian fisheries resources. Bureau of Resource Sciences, Canberra

Kendall AW, Naplin NA (1981) Die]-depth distribution of summer ichthyoplankton in the middle Atlantic Bight. Fish Bull US 79:705-726

Kingsford MJ (1990) Linear oceanographic features: a focus for research on recruitment processes. Aust J Ecol 15: $391-401$

Kingsford MJ, Suthers IM (1994) Dynamic estuarine plumes and fronts: importance to small fish and plankton in coastal waters of NSW, Australia. Cont Shelf Res 14:655-672

Kuiter RH (1993) Coastal fishes of south-eastern Australia. Crawford House Press, Bathurst

Lavett Smith C, Tyler JC, Stillman L (1987) Inshore ichthyoplankton: a distinctive assemblage? Bull Mar Sci 41 $432-440$

Leadbitter D, Pollard DA (1987) Fishing and diving activities in Jervis Bay. Wetlands 6:65-74

Leis JM, Goldman B (1987) Composition and distribution of larval fish assemblages in the Great Barrier Reef lagoon, near Lizard Island, Australia. Aust J Mar Freshw Res 38: $211-223$

Leis JM, Rennis DS (1983) The larvae of Indo-Pacific coral reef fishes. NSW Uni Press, Sydney, and Uni Hawaii Press, Honolulu

Loeb VJ (1979) Vertical distribution and development of larval fishes in the north Pacific central gyre during summer. Fish Bull US 77:777-793

Loeb VJ (1980) Patterns of spatial and species abundance within the larval fish assemblage of the North Pacific Gyre during late summer. Mar Biol 60:189-200

Loeb VJ, Kellermann AK, Koubbi P, North AW, White MG (1993) Antarctic larval fish assemblages: a review. Bull Mar Sci 53:416-449

Mackas DL (1984) Spatial autocorrelation of plankton community composition in a continental shelf ecosystem. Limnol Oceanogr 29:451-471

Marliave JB (1986) Lack of planktonic dispersal of rocky reef intertidal fish larvae. Trans Am Fish Soc 115:149-154

Maxwell JGH, Cresswell GR (1981) Dispersal of tropical marine fauna to the Great Australian Bight by the Leeuwin Current. Aust J Mar Freshw Res 23:493-500

McClean-Padman J, Padman L (1991) Summer upwelling on the Sydney inner continental shelf: the relative roles of local wind forcing and mesoscale eddy encroachment. Cont Shelf Res 11:321-345

McGowen GE (1993) Coastal ichthyoplankton assemblages, with emphasis on the southern California Bight. Bull Mar Sci 53:692-722

Middleton JH (1987) Sydney deepwater outfalls environmental monitoring program pilot study, Vol 2, Oceanographic component. Manly Hydraulics Laboratory, Sydney

Miller TJ, Crowder LB, Rice JA, Marschall EA (1988) Larval size and recruitment mecanisms in fishes: towards a conceptual framework. Can J Fish Aquat Sci 45:1657-1670

Minami T, Tamaki T (1980) Offshore and nearshore distributional patterns of fish larvae along the San-in coast, the Sea of Japan. Jpn J Ichthyol 27:156-164
Miskiewicz AG (1986) The season and length at entry into a temperate Australian estuary of the larvae of Acanthopagrus australis, Rhabdosargus sarba and Chrysophrys auratus (Teleotei: Sparidae). In: Uyeno $T$, Arai $R$, Taniuchi T, Matsuura K. (eds) Indo-Pacific fish biology: Proceedings of the Second International conference on Indo-Pacific fishes. Ichthyol Soc Jpn, Tokyo, p 740-747

Miskiewicz AG (1987) Taxonomy and ecology of fish larvae in Lake Macquarie and New South Wales coastal waters. PhD thesis, University of New South Wales, Sydney

Miskiewicz AG (1989) The distribution of tropical/coral reef fish larvae in temperate waters along the New South Wales coast of Australia. Rapp P-V Reun Cons Perm Int Explor Mer 191:452 (abstract only)

Moser HG, Charter RL, Smith PE, Ambrose DA, Charter SR, Meyer CA, Sandknop EM, Watson W (1993) Distributional atlas of fish larvae and eggs in the California Current Region: taxa with 1000 or more total larvae, 1951-1984. Calif Coop Oceanic Fish Invest Atlas 31

Moser HG, Charter RL, Smith PE, Ambrose DA, Charter SR, Meyer CA, Sandknop EM, Watson W (1994) Distributional atlas of fish larvae in the California Current Region: taxa with less than 1000 total larvae, 1951-1984. Calif Coop Oceanic Fish Invest Atlas 32

Nilsson CS, Cresswell GR (1981) The formation and evolution of East Australian Current eddies. Prog Oceanogr 9: $133-183$

Norcross BL, Shaw RF (1984) Oceanic and estuarine transport of fish eggs and larvae: a review. Trans Am Fish Soc 113. $153-165$

Olivar MP, Beckley LE (1994) Influence of the Agulhas Current on the distribution of lanternfish larvae off the southeast coast of Africa. J Plankton Res 16:1759-1780

Palomera I (1991) Vertical distribution of eggs and larvae of Engraulis encrasicolus in stratified waters of the western Mediterranean. Mar Biol 111:37-44

Richards WJ, McGowen T, Leming T, Lamkin JT, Kelley S (1993) Larval fish assemblages at the loop current boundary in the Gulf of Mexico. Bull Mar Sci 53:475-537

Richardson SL, Laroche JL, Richardson MD (1980) Larval fish assemblages and associations in the North-east Pacific Ocean along the Oregon coast, winter-spring 1972-1975. Estuar Coast Shelf Sci 11:671-699

Sabates A (1990) Distribution patterns of larval fish populations in the northwestern Mediterranean. Mar Ecol Prog Ser 59:75-82

Sabates A, Maso M (1992) Unusual larval fish distribution pattern in a coastal zone of the western Mediterranean. Limnol Oceanogr 37:1252-1260

Sabates A, Olivar MP (1996) Variations of larval fish distribution associated with variability in the location of a shelfslope front. Mar Ecol Prog Ser 135:11-20

Sameoto DD (1984) Environmental factors influencing diurnal distributions of zooplankton and ichthyoplankton. J Plankton Res 6:767-791

Sinclair M, Iles TD (1985) Atlantic herring (Clupea harengus) distributions in the Gulf of Maine - Scotian shelf area in relation to oceanographic features. Can J Fish Aquat Sci 42:880-887

Smith KA, Gibbs MT, Middleton JH, Suthers IM (1999) Shortterm variability in larval fish assemblages of the Sydney shelf: tracers of hydrographic variability. Mar Ecol Prog Ser (in press)

Steffe AS (1989) Tidal and diel variations in the abundances of larval fishes in Botany Bay, NSW, with emphasis on silver biddy Gerres ovatus (F: Gerreidae) and gobies (F: Gobiidae). Proc Linn Soc NSW 111:225-232 
Steffe AS, Pease BC (1988) Diurnal survey of ichthyoplankton abundance, distribution and seasonality in Botany Bay, New South Wales. Proc Linn Soc NSW 1 10:1-10

White N, Church J (1986) Salinity, temperature and pressure data from the Australian Coastal Experiment. CSIRO Marine Laboratories Report No. 188. CSIRO, Hobart.

Wiafe G, Frid CIJ (1996) Short-term temporal variation in

Editorial responsibility: Otto Kinne (Editor),

Oldendorf/Luhe, Germany coastal zooplankton communities: the relative importance of physical and biological mechanisms. J Plankton Res 18: $1485-1501$

Young PC, Leis JM, Hausfeld HF (1986) Seasonal and spatial distribution of fish larvae in waters over the north west continental shelf of Western Australia. Mar Ecol Prog Ser 31:209-222

Submitted: May 8, 1998; Accepted: July 2, 1998 Proofs received from author(s): December 14, 1998 